\title{
KAZIMIERZ POZNAŃSKI
}

\author{
$\stackrel{\circ}{\text { III }}$

\section{KONFUCJANIZM JAKO EKONOMIA MORALNA}

\begin{abstract}
Kazimierz Poznański, Konfucjanizm jako ekonomia moralna [Confucianism as a moral economy] edited by W. Banach, M.A. Michalski, J. Sójka „',Zzłowiek i Społeczeństwo" vol. XLVI: Między Chinami a Zachodem. Pytanie o źródła chińskiego sukcesu gospodarczego [Between China and the West. An inquiry into the sources of the Chinese economic miracle], Poznań 2018, pp. 11-42, Adam Mickiewicz University. Faculty of Social Sciences Press. ISSN 0239-3271.
\end{abstract}

Western economic system is usually called "democratic capitalism". But how should be called the system in today's China? China is not a capitalist economy, but a market economy without capitalism. She is also a democracy but without direct voting for the highest posts. The doctrinal roots of "democratic capitalism" are in liberalism and the Chinese system is ingrained in Confucianism. For this reason, what is in use in China can be called "Confucian system" or, alternatively "Confucian meritocracy". This kind of meritocracy is not limited to Chinese state, it operates through entire society. As Confucians argue, state is a function of family. Thus, only when family is a meritocracy, so is the state, actually the whole society. Chinese meritocracy is an ethical concept, because in Confucian tradition "merit" means "virtue". Two thousand years old, Chinese system of ethics has continued. But two hundred years ago, parallel Western ethical vision of society has been assaulted by liberalism. This marked a gigantic split between the two civilizations. Escaping from ethics to call it - logic, is the reason why liberalism has been failing to accurately reflect economic reality. As a consequence, Western economies work below their potential. In contrast, sticking to her ethical philosophy - of life - China has been excelling. To properly address this dynamic, it is necessary to determine what constitutes Chinese view of economy as a study of wealth. Not yet formalized, it is her peoples'"second nature". It all begins with a claim that goal of people is the extension of life to next generations. But liberalism - with "liberal (classical) economics" - argues that the goal is an "instant gratification", i.e., consumption of goods. In pursuit of personal satisfaction, individuals face no moral dilemma. But since life is a gift, for Confucians choices are moral. Chinese reject the liberal notion of scarcity and claim abundance of resources. With excess, people can "afford" morality which is about sharing. Since there is no need for live-or-die competition for resources, to survive people need only to work. For Confucians, not market but family is the prime form of organization. This is so, since morality comes from family. Market can enhance efficiency only when "embedded" in morality. This is true about other key institution - state. China continues her "success story" by restoring Confucian past, with meritocracy at the core. To stimulate its economy, 
Western civilization also needs a return to the past. It needs to remake its mainstream liberalism by returning to roots as formulated by proto-liberalism. Focused on morality and family, this approach has been renewed by Joseph Schumpeter and the Austrian School. Parallel reforms may bring two grand civilizations close by again.

Emerytowany profesor University of Washington, Seattle

\section{Wprowadzenie}

Chiny odnoszą gigantyczne sukcesy gospodarcze dzięki temu, że nie porzuciły swojej konfucjańskiej tradycji, aby dołączyć do rewolucji przemysłowej - oto moja główna teza. Tylko Zachód dwieście lat temu, w imię postępu, rozpoczął tę rewolucję. Oznaczało to pójście w stronę liberalizmu i całej jego doktryny. Zerwane zostały w ten sposób bliskie więzi między tymi cywilizacjami. Tym, co przez wieki łączyło zachodnie i chińskie społeczności, jako dwie największe cywilizacje, było rozumienie ekonomii jako formy etyki, to znaczy działania na rzecz innych ludzi motywowanego miłością. Były w tej kwestii różnice, ponieważ w ujęciu chińskim, czyli konfucjańskim, moralnym celem człowieka jest dobro rodziny, a w tradycji zachodniej chodzi głównie o dobro ogółu. W obu sposobach myślenia wierzy się, że impuls moralny pochodzi z miłości. W podejściu zachodnim jest to jednak bardziej miłość powszechna w stosunku do naszych bliźnich, natomiast tradycja chińska stawia na miłość rodzicielską ${ }^{1}$. Podczas gdy Chiny kontynuują swoje tradycyjne podejście do etyki i miłości, Zachód zrezygnował z własnej tradycji, porzucając etykę i miłość jako podstawowe kategorie analityczne.

Wydaje się, że Chiny są na prostej drodze do tego, aby stać się centrum światowej gospodarki, co tylko potęguje wrażenie, że osłabiony świat zachodni doświadcza kryzysu idei. Pojawia się nawet perspektywa możliwości intelektualnego zdominowania Zachodu przez Azję, głównie Chiny. Faktem jest, że wraz z rosnącą siłą materialną rola Chin przebija się coraz bardziej do zbiorowej świadomości. Droga do powszechnego przejęcia wschodnich sposobów myślenia byłaby jednak długa. Przeszkodą jest także to, że chińskie wzorce myślenia tak bardzo różnią się od zachodnich, iż trudno tu o porozumienie obu stron. Z tego powodu nierealistyczne byłoby oczekiwanie większego wpływu Wschodu na powszechne sposoby

1 Por. J.Y. Lin, Benti \& Changwu: Dialogues on Methodology in Economics, Cengage Learning Asia, Peking University Press, Peking 2005. 
myślenia o świecie. Tak jak nie powiodła się westernizacja świata, tak nie może się udać narzucenie wschodniego sposobu myślenia. Skądinąd nie jest ono nawet konieczne, ponieważ Zachód może próbować powstrzymać swój upadek własnymi siłami. Jednocześnie, nie przejmując konfucjanizmu, ludzie Zachodu mogą się nim inspirować. Przede wszystkim jednak świat zachodni ma szansę na wewnętrzną odnowę poprzez powrót do przeszłości, czyli do wczesnego liberalizmu (protoliberalizmu) zgodnego z interpretacją Josepha Schumpetera, reprezentanta szkoły austriackiej².

Jak państwo chińskie odpowie na te wyzwania? Wykorzystywanie siły militarnej raczej nie wchodzi w grę. Trzymając się konserwatywnych wartości, Chiny najprawdopodobniej będą kontynuować swój ustalony modus operandi. Ich rola na scenie międzynarodowej będzie musiała być zgodna z przyjętą konfucjańską koncepcją państwa. Zasady obowiązujące wewnątrz nie mogą się różnić od zasad obowiązujących w stosunkach z innymi krajami. W tradycji chińskiej główną funkcją państwa jest zapewnienie dyscypliny moralnej społeczeństwa. Preferowanym instrumentem władzy państwowej w konfucjanizmie nie jest przymus ani przemoc, ale moralny przykład płynący z przestrzegania przyjętych wartości. Postać mędrca, nigdy żołnierza, jest uosobieniem takiego oświeconego - opartego na cnocie państwa. Tak więc państwo chińskie może być przydatne w rozwiązywaniu globalnych problemów głównie jako przywódca duchowy, być może obok innych tego typu przywódców. Mówiąc o zmieniającym się porządku świata, znany amerykański polityk Henry Kissinger również wyklucza chińskie podboje w roli światowego hegemona. Przewiduje natomiast, że główną ambicją Chin w okresie politycznej reorganizacji świata będzie powrót do roli „głównego doradcy całej ludzkości”3.

\section{Wyolbrzymione zagrożenia}

Dominuje pogląd, że świat jest w trakcie rekonfiguracji, którą Chiny najprawdopodobniej wykorzystają do zdobycia kontroli, czy wręcz rządów nad nim. Wprawdzie byłoby to dość trudne zadanie, ale nie niemożliwe

2 J. Schumpeter, Kapitalizm, socjalizm, demokracja, Wydawnictwo Naukowe PWN, Warszawa 2009 (pierwsze wydanie - 1942); por. K. Poznanski, Poland's Protracted Transition: Institutional Change and Economic Growth in 1974-1994, Cambridge University Press, Cambridge 1996.

3 E. Luce, Henry Kissinger: „, We are in a very, very grave period”, „Financial Times” July 20/2018. 
do wykonania ${ }^{4}$. Taka sytuacja oznaczałaby, oczywiście, koniec zachodniej hegemonii, czyli „Pax Americana” jako przedłużenia XIX-wiecznego „Pax Britannica”. Rodzić to może wizję ogólnoświatowego konfliktu przypominającego wcześniejsze walki o hegemonię, które doprowadziły do pierwszej, a następnie drugiej wojny światowej. Zmagania te w żadnym wypadku nie zostały sprowokowane przez Chiny. Fakty są takie, że w historii Chin prawie nie ma wojen prowadzonych w celu zdobycia kontroli terytorialnej. Wskazują na to badania historyczne dotyczące częstotliwości agresywnych - ekspansjonistycznych - wojen w przeciwieństwie do wojen obronnych. Wnikliwą analizę pokojowej natury Chin przeprowadził wybitny polski sinolog Krzysztof Gawlikowski ${ }^{5}$. Wspomniane zjawisko pokazuje też historyczna analiza amerykańskiego analityka politycznego Davida Kanga ${ }^{6}$. Jego badania obejmują historię wojen z udziałem Chin za panowania długowiecznej dynastii Ming w okresie 1368-1644, a także później, aż do 1841 r. (łącznie prawie pięćset lat).

Jest to okres przed przybyciem zachodnich mocarstw kolonialnych, które wywołały dwie wojny opiumowe, a dokładniej - małe potyczki z bezbronnymi Chinami. Ciągnęły się one w latach 1839-1842, a następnie 1856-1860. Kang przytacza opinie, że przez cały ten okres kilku stuleci bardzo niewiele wojen wywołały Chiny. Co najważniejsze, w porównaniu z trzema sąsiadującymi z nimi krajami - Koreą, Wietnamem i Japonią - zdecydowanie powstrzymywały się od agresji. Z drugiej strony miały częste, ale bardzo ograniczone konflikty z nomadycznymi najeźdźcami. Stosunki z trzema sąsiadującymi narodami były regulowane przez system trybutarny. Chiny, jako lider, oczekiwały od sąsiadów pokojowych zamiarów, ofiarowując w zamian gwarancje bezpieczeństwa, dostęp do swoich ogromnych rynków i dzielenie się swoją atrakcyjną kulturą, czyli konfucjanizmem. W dużej mierze sąsiedzi decydowali się na wzbogacanie własnej kultury, otwierając się na język mandaryński czy klasyczną poezję. Ten wpływ był ogromny, do dziś więc kraje te dość ściśle trzymają się starożytnych tradycji chińskich.

W 1592 r. Japonia potężną armią liczącą 160000 żołnierzy dokonała inwazji na Koreę i powtórzyła to w 1598 r., tym razem wysyłając 140000

${ }^{4}$ Por. M. Jacques, When China Rules the World: The End of the Western World and the Birth of a New Global Order, The Penguin Press, London 2009.

${ }^{5}$ K. Gawlikowski, Zachodnie i konfucjańskie podejścia do wojny, w: A. Zielonka, B. Zemka (red.), Chińska konfucjańska tradycja, Wyd. Uniwersytetu Jagiellońskiego, Kraków 2008.

${ }^{6}$ D. Kang, East Asia Before the West: Five Centuries of Trade and Tribute, Columbia University Press, New York 2010. 
żołnierzy. Japońskie wojska stanęły w obliczu 50 000-100 000 koreańskich żołnierzy oraz 100000 Chińczyków i przegrały tę wojnę. Łączne straty wyniosły 100 000-200 000 osób. Trzysta lat przed tą wojną i trzysta lat po niej w regionie panował pokój - w sumie to sześćset lat. W tym czasie same Chiny nie zainicjowały nawet jednej wojny z zamiarem podboju. Podczas wspomnianej wojny w latach 1592-1598, w ramach zobowiązań trybutarnych, Chińczycy przybyli ze swoimi siłami, aby pomóc sojuszniczej Korei w walce z Japończykami. W tym okresie państwo chińskie było najsilniejsze, ale nie dążyło do dominacji terytorialnej. Należy zauważyć, że Chiny nadal mają takie same granice na południu - z Wietnamem - jak setki lat temu. Trzeba przyznać, że granica północna - z Tybetem - została przesunięta, jednakże uczynili to Mongołowie, gdy pustoszyli Chiny. Jeśli chodzi o niepoddających się żadnej kontroli nomadów, wciśniętych między kwitnące Chiny i niedostępną Rosję, te prymitywne plemiona po prostu zniknęły z mapy.

Warto dodać kilka interesujących szczegółów do opisu tych dwóch interwencji w konflikt między Japonią a Koreą. Japonia przegrała wojnę 1592-1598, płacąc za to cenę dziesiątek tysięcy ofiar. Sama armia koreańska nie byłaby wystarczająca. O losach wojny zadecydowała techniczna przewaga Chińczyków, głównie na morzu. Pokonane japońskie wojska opuściły półwysep bez podpisania pokoju. Zabrały ze sobą około 50000 więźniów, głównie rzemieślników, prawdopodobnie wraz z ich rodzinami. Wywiozły również tysiące chińskich książek, zwoje obrazów na papierze i jedwabiu oraz mnóstwo religijnych kamiennych rzeźb. Chińskie wojsko poniosło porównywalne straty w ludziach. W rezultacie rządząca dynastia Ming, z cesarskim skarbcem opróżnionym z powodu wydatków wojennych, stała się ofiarą podboju Mandżurów, którzy w 1644 r. zajęli Pekin.

Kontrast z Europą - jeśli chodzi o problem agresji militarnej - jest bardzo widoczny. U podstaw struktur europejskich nie leżał system trybutarny, lecz zachodnia idea systemu opartego na równowadze sił. Wyrazem tej idei jest „pokój westfalski” z 1648 r., który zagwarantował suwerenność państw jako konstrukcję prawną. W takich okolicznościach nie powinno być sporów terytorialnych lub powinny one być rzadsze. Jak pokazują statystyki, mimo to w tym czasie kontynent był wstrząsany dziesiątkami wojen, i to na zdecydowanie większą skalę. Przykładem może być choćby wojna trzydziestoletnia, zakończona traktatem westfalskim. Wojnę tę, pomiędzy Francją a dynastią Habsburgów, prowadzono na tle religijnym w zasadzie prawie wyłącznie rękoma wojsk najemnych. Wojny napoleońskie toczyły się w znacznie krótszym okresie, w latach 1803-1815, ale były ogólnie bardziej 
krwawe, ponieważ pochłonęły od 2,5 do 3 milionów strat tylko wojskowych (z czego pół miliona stanowili Rosjanie i kolejne pół miliona Francuzi).

Można oczywiście zapytać, czy dzisiejsze Chiny nie są już mniej pokojowo nastawione. Nie ma jednak żadnych konkretnych dowodów na taką zmianę priorytetów. Chiny nadal wykazują szczególną niechęć do wojny, podobnie jak cała Azja Wschodnia (z wyjątkiem krótkiego konfliktu Chin z Wietnamem). Zgodnie z zachodnią koncepcją równowagi sił, gdy układ $\mathrm{w}$ regionie zmienia się z powodu pojawienia się nowego, bardziej wpływowego hegemona - przywódcy innych krajów muszą dostosować swoją strategię. Słabsze państwa, o słabszej gospodarce i mniejszych zdolnościach militarnych, wchodzą w sojusze, aby zabezpieczyć się przed powstającym zagrożeniem. Chiński cud gospodarczy sprawił, że dzisiejsze Chiny zyskały ogromną przewagę. Zgodnie z tą koncepcją polityczną należałoby się spodziewać wojny, która wybuchnie w regionie przeciwko Chinom, aby utrzymać je w ryzach. Tak się jednak nie dzieje, a żaden z sąsiednich krajów nie myśli o konfrontacji militarnej. Powodem jest to, że - jak przypuszczam na podstawie znajomości Chin - nie odczuwają one realnego zagrożenia dla swojej suwerenności (podobnie jak inne kraje, w których Chiny lokują ogromne inwestycje zagraniczne).

\section{Światopogląd konfucjański}

Jaka jest owa mądrość Chin w kwestii etyki w ekonomii, która mogłaby uczynić ją źródłem porad dla Zachodu? Nie da się tego łatwo ustalić, ponieważ wiedza o Chinach, tych rzeczywistych, oraz o tym, jak sami Chińczycy postrzegają ekonomię jako dyscyplinę, jest na Zachodzie bardzo ograniczona. Stanowisko Zachodu jest jasne: twierdzi się, że Chińczycy nie mają własnej teorii ekonomii. Dominuje pogląd, że jest tylko jeden naukowy światopogląd ekonomiczny: zachodni. Myśl tę podzielają zachodni ekonomiści i Chińczycy, z których duża część studiowała ekonomię na Zachodzie. Tą powszechnie uznaną szkołą jest, oczywiście, szkoła liberalna, zapoczątkowana dwieście lat temu, a zatem Chińczycy powinni trzymać się zachodniego myślenia o świecie. Prawda jest jednak zupełnie inna, Chińczycy bowiem od dłuższego już czasu dysponują własną myślą ekonomiczną, która jednak wciąż ma charakter nieformalny. Ich ekonomia jest zawarta w starożytnym konfucjanizmie jako ugruntowanej metodzie życia i odnosi się do dwóch jego podstawowych wymiarów, czyli wizji świata i powiązanych z nią wzorców działania. 
Założyłem, że cywilizacja chińska musi najprawdopodobniej być tak samo bogata i złożona jak zachodnia (czy europejska), i na tej podstawie udało mi się zidentyfikować osiem zasad ekonomii konfucjańskiej . Ten system myślowy okazuje się zupełnym zaprzeczeniem zachodniej, liberalnej (klasycznej) ekonomii. Konfucjańskie podejście zaczyna się od twierdzenia, że świat jest synonimem życia, a więc studiowanie świata to studiowanie życia. Badanie życia polega przede wszystkim na wyjaśnieniu, skąd ono pochodzi. Krótka odpowiedź brzmi: z ludzkiej woli życia. Podstawowym wyrazem tej woli jest posiadanie dzieci, własnych lub nie. W konsekwencji konfucjańscy myśliciele lub ekonomiści zakładają, że głównym celem jednostek - jako podmiotów gospodarczych - jest przedłużenie życia, a ściślej, kontynuacja linii rodzinnej. Życie zakłada moralność rozumianą jako odpowiedzialność za innych, ponieważ posiadanie dzieci - postrzegane przy tym jako dar jest ekonomiczną ofiarą, największą z możliwych. Ten wymiar etyczny praktycznie nie występuje w konkurencyjnym światopoglądzie liberalnym, który jako cel zakłada tak zwaną natychmiastową gratyfikację lub - jak to się nazywa wśród liberałów - krańcową użyteczność odzwierciedloną w ściśle mierzalnej prywatnej konsumpcji dóbr materialnych.

Jak twierdzą konfucjaniści, dzięki szczodrości natury zasoby (np. woda, gleba lub powietrze) nie są dobrem ograniczonym, „rzadkim”, ale występują w obfitości, a właściwie w nadmiarze. Konfucjaniści są bardzo stanowczy w swoim zaskakującym dla liberałów twierdzeniu ${ }^{8}$. W ich przekonaniu ludzkość otrzymuje więcej, niż jest to niezbędne, ponieważ natura nie daje ludziom życia po to, aby je zabrać przez narzucanie nieludzkich warunków. W ten sposób, z powodu obfitości, ludzie mogą „pozwolić” sobie na moralność, dzieląc się swoimi dobrami z innymi, bez żadnego niebezpieczeństwa dla siebie. W warunkach obfitości zwycięską strategią dla jednostek nie jest przejmowanie zasobów - takich jak wspomniane gleba, woda czy powietrze od siebie nawzajem, ale raczej praca polegająca na przekształcaniu bogactwa zasobów w bogactwo potrzebnych dóbr. Ludzie podejmują ten wysiłek przede wszystkim nie dla siebie, ale z troski o innych i z miłości, zwłaszcza do własnej rodziny. Ilość pracy wykonywanej przez jednostki w celu zwielokrotnienia bogactwa nie jest więc funkcją tak zwanej użyteczności marginalnej, ale raczej pochodną postaw moralnych. Czyni to moralność główną siłą napędową wzrostu gospodarczego, swoistym czynnikiem produkcji.

7 Por. K. Poznanski, Confucian Economics: The World at Work, „World Review of Political Economy” 6/2/2015.

8 Por. ibidem. 
W ekonomii konfucjańskiej zakłada się, że rodzina jest podstawowym, jeśli nie wyłącznym, źródłem moralności. Dzieje się tak, ponieważ to w niej dokonywane są najbardziej fundamentalne wybory moralne, nie tylko wspomniane już decyzje dotyczące wydawania dzieci na świat, ale także wybór w sprawie pomocy rodzicom i osobom starszym w ogóle. Według konfucjanistów największym obowiązkiem jednostek jest nieograniczone poszanowanie własnych rodziców. Jest to postawa oraz norma, którą nazywa się „synowską pobożnością”. Ten centralny element etyki dotyczy rodziny również z innych powodów. Aby móc przestrzegać norm moralnych, wraz z wszystkimi ograniczeniami, które one nam narzucają, należy akceptować określoną moralność. Według konfucjanistów rodzina jest miejscem, komórką społeczną, w którym motywacja do działania moralnego jest najsilniejsza z możliwych, właśnie z powodu więzów krwi. Ten szczególny rodzaj motywacji rodzi miłość jako impuls moralny, który pochodzi głównie z macierzyństwa, związku matki z dzieckiem.

Ponieważ moralność i skuteczność są tutaj ze sobą ściśle powiązane, rodzina jako źródło moralności - a nie rynek jako rodzaj instytucji - jest najskuteczniejszą formą organizacji działalności gospodarczej. Poświęcenie rodzinie, jako grupie, musi być oczywiście silniejszym motywem do pracy niż interes własny jednej osoby. Dlatego większość produkcji czy majątku pochodzi zazwyczaj z firm rodzinnych. Jest to sprzeczne z liberalnym założeniem, że podstawową jednostką produkcji, animatorem rynku jest niezależna jednostka, zwana także ,autonomiczną”. Taka osoba nie jest ograniczona etyką odpowiedzialności za innych w rodzinie lub poza nią. Przynajmniej w ramach liberalnego porządku wolnego rynku zasady moralne nie są ponoć konieczne do zapewnienia najefektywniejszego wykorzystania czynników produkcji. A zatem najważniejsze jest to, że podczas gdy liberalna ekonomia, jako teoria społeczna, moralne podstawy działania traktuje obojętnie - ekonomia konfucjańska jest wręcz formą etyki, nawet w bardzo skrajnej postaci ${ }^{9}$.

\section{System mandaryński}

Wybór rodziny, a nie rynku, jako kluczowej instytucji nie oznacza, że ekonomia konfucjańska jest niechętna rynkom. Przeciwnie, podobnie jak liberałowie, konfucjańscy ekonomiści są przekonani, że rynki to bardzo użyteczna

9 Por. K. Poznanski, State Condition, Foreign Influence and Alternative Models of Market Reforms in China, Russia and Eastern Europe, „International Critical Thought” 2/3/2012. 
instytucja. Przeciwstawiają się jednak wolnemu rynkowi, na którym ceny towarów, generowane przez bezosobową konkurencję, dyktują indywidualne wybory. Zamiast tego uważają, że wybory zależą głównie od zasad moralnych, wartości, wywodzących się z ludzkiej praktyki. Ze względu na swój etyczny charakter ekonomia konfucjańska faworyzuje rynek zakorzeniony w moralności. Na rynku, który spełnia te wymagania, głównymi aktorami są rodziny, będące wyznacznikiem zasad moralnych. Tę systemową odmianę, w której podstawowymi graczami są nie jednostki, lecz rodziny, najlepiej można określić jako rynek rodzin lub rynek familijny ${ }^{10}$. Trzeba przy tym, oczywiście, pamiętać, że rodziny mogą się różnić swoją specyficzną formą czego jednym z przykładów jest tak zwany chiński klan.

W przeciwieństwie do zachodniego wyobrażenia o Chinach jako na wskroś autokratycznego systemu konfucjańscy myśliciele nie odrzucają automatycznie idei państwa minimalnego. Tak naprawdę zdecydowanie opowiadają się za takim właśnie państwem, ale w formie fundamentalnie różnej od propozycji liberalnej. Wersja konfucjańska nie podkreśla wagi zakresu wolności jednostki, ale wagę sytuacji rodziny, jej niezależności. Co więcej, podczas gdy liberałowie postrzegają działalność państwa jako opartą na przymusie, konfucjaniści twierdzą, że siła państwa bierze się z zasług, to znaczy z przywództwa moralnego, które osiąga się głównie poprzez wzorowe, godne naśladowania zachowanie. Najważniejszym atrybutem państwa w jego działalności gospodarczej jest poziom moralny, co powoduje, że właściwym terminem na określenie takiego systemu jest „państwo moralne”. Inni autorzy, również zgodnie z podstawowymi założeniami ekonomii konfucjańskiej, twierdzą, że główną metodą regulowania stosunków między ludźmi jest rytuał. Dlatego też nazywają ten rodzaj konfucjańskiej instytucji „państwem opartym na rytuale”.

Według liberałów kwestia dystrybucji bogactwa powinna być pozostawiona wolnemu rynkowi. Taki rynek zapewnia, że ci, którzy wnoszą większy wkład w ogólne bogactwo, otrzymują większe nagrody, nierówność jest więc nieunikniona. Z drugiej strony konfucjańscy ekonomiści odmawiają powierzenia bogactwa rynkowej dystrybucji społecznej, ponieważ mogą przekształcić konkurencję w poszukiwanie czynszu monopolistycznego. To nieuchronnie prowadzi do zerwania związku między wysiłkiem i nagrodą, potencjalnie nawet drastycznego. Konfucjańska ekonomia wymaga, aby ludzie mieli bardzo podobne, ale nie identyczne udziały w bogactwie. Akceptuje zatem liberalny postulat powiązania dochodu z wynikami jednostki.

\footnotetext{
${ }^{10}$ Por. K. Poznanski, Confucian Economics...
} 
Jednakże myśliciele konfucjańscy nie sądzą, że ta zasada musi prowadzić do znacznego zróżnicowania zamożności. W ich opinii ludzie nie różnią się tak bardzo pod względem zdolności fizycznych lub umysłowych, nie mają więc podstawy rażąco duże różnice płacowe. Ów postulat równości jest jednym z przejawów tego, że konfucjanizm - z jego intrygującą ekonomią - jest zdecydowanie socjalistyczny lub „socjalizujący”11.

Zgodnie z moim opisem ekonomia konfucjańska ma własną teorię systemów, rozumianych jako kompleksowe zespoły instytucji lub zasady gry regulujące gospodarkę. W mojej najnowszej książce ${ }^{12}$ przedstawiam nowe teoretyczne podejście do systemów gospodarczych, zgodne z logiką doktryny konfucjańskiej. To jest prawdziwie radykalne odejście od dominującej liberalnej teorii omawianych systemów. Teoria ta skupia się na dwóch instytucjach gospodarczych: rynku i państwie. Zależnie od roli przypisywanej obu tym elementom wyłaniają się tutaj dwa podstawowe systemy gospodarcze. Jeden z nich to oparty na rynku kapitalizm, drugi - oparty na państwie socjalizm. Kapitalizm jest systemem wydajnym, natomiast socjalizm jest niewydajny. Bierze się to stąd, że rynek (wraz z konkurencją) jest instytucją zdrową, a państwo (ze swoją biurokracją) - zdaniem liberałów - chorą. To dlatego kapitalizm ma szansę trwać, a socjalizm jest nieuchronnie skazany na upadek.

Ten kategoryczny podział liberałów załamuje się w obliczu obecnego chińskiego cudu gospodarczego, osiągniętego w wyniku reform rozpoczętych w 1978 r. Fenomenalne przyspieszenie ze strony Chin nie jest sukcesem rynków, które wyparły państwo. I nie jest też tak, że rynki pojawiają się automatycznie, gdy tylko państwo przestaje interweniować w gospodarkę. Sukces Chin polegający na ekspansji sił rynkowych był możliwy dzięki państwu, które zachowało daleko idącą kontrolę nad produkcją i podziałem. Dlatego chińska gospodarka nie jest w swej istocie kapitalistyczna. Opiera się na rynku, ale w żadnym razie nie jest kapitalistyczna. Wynika z tego, że jest to gospodarka rynkowa i jednocześnie socjalistyczna. Ocena taka współbrzmi z oficjalnym stanowiskiem władz, które określają obecny system jako socjalistyczną gospodarkę rynkową lub, w skrócie, socjalizm rynkowy. Nie jest to chwyt propagandowy partii rządzącej, która programowo definiuje się jako socjalistyczna. Trzeba przy tym pamiętać, że właściwie rozumiana

${ }^{11}$ Por. H. Chen, The Economic Principles of Confucius and his School, Honolulu University Press, Honolulu 1911.

${ }^{12}$ K. Poznański, Konfucjańska ekonomia jako alternatywa wobec skrajnego liberalizmu, w: E. Mączyńska (red.), Ekonomia i polityka. Wokół teorii Grzegorza W. Kołodko, Wydawnictwo Naukowe PWN, Warszawa 2019. 
myśl konfucjańska ma bardzo silne elementy socjalistyczne, a nawet jest formą socjalizmu. W związku z tym najwłaściwsze jest nazywanie chińskiego porządku gospodarczego „systemem konfucjańskim”.

\section{Socjalizm rynkowy}

Ze swoim liberalizmem, a raczej neoliberalizmem, dzisiejszy Zachód wydaje się zagrożeniem dla siebie, natomiast ze swoim starym, ale nie archaicznym, konfucjanizmem Chiny nie odnajdują się w tej sytuacji. Fakt, że światopogląd Zachodu jest zdeterminowany głównie przez liberalizm, jest bezdyskusyjny. Niemniej pytanie, jak dalece konfucjanizm rządzi obecnymi Chinami, pozostaje otwarte. Moim zdaniem byłoby naiwnością zakładać, że w wyniku reform lub innych sił mogłaby nastąpić poważna erozja postulatów konfucjańskich. Można dyskutować jedynie nad wzrostem wpływów chińskich, być może nawet w skali globalnej. W Chinach toczy się debata na temat prawdziwej roli doktryny konfucjańskiej. W oficjalnych kręgach często mówi się, że kraj ten wszedł w fazę odnowy cywilizacji i że jest to element globalnego odrodzenia różnych istniejących do dzisiaj starych centrów kulturowych czy cywilizacji. Zdaniem bardzo znanego chińskiego ekonomisty Justina Yifu Lina ta odnowa w Chinach oznacza przede wszystkim dalszą zmianę w kierunku konfucjanizmu ${ }^{13}$. W związku z tym obecny cud gospodarczy należy przypisać nie reformom rynkowym, ale kulturze. Udział reform w osiągnięciu tego cudu polega raczej na tym, że po prostu pozwoliły one odblokować starożytną - konfucjańską - kulturę jako główne źródło talentu i pomysłowości ludzi.

Konfucjanizm został wielokrotnie uznany za relikt przeszłości. Ataki te nasiliły się po 1945 r., kiedy do władzy doszli komuniści. Tyle tylko, że już podczas tak zwanej wymuszonej industrializacji paradoksalnie rozpoczęło się powolne odradzanie konfucjanizmu. Okazało się, że nawet zmiany tak drastycznie jak te z 1945 r. nie mogły zniszczyć prastarej bazy, w której zakorzeniona jest chińska kultura. Okazało się również, że ostra walka z tą odziedziczoną filozofią społeczną nie jest konieczna, ponieważ konfucjanizm jest zbieżny - choć nie identyczny - z marksizmem, przyjętym za oficjalną ideologię. Prekursor naukowych badań nad chińską myślą ekonomiczną Huan-Chang Chen jako jedyny wysunął tezę, że konfucjanizm

13 Por. J.Y. Lin, Demystifying China Economy, Cambridge University Press, Cambridge 2017. 
zawiera własną ekonomię ${ }^{14}$. Niemniej jego zdaniem wykazuje ona bardzo silne podobieństwo do liberalizmu. Dla ścisłości wypada dodać, że rozważając chińskie zasady podziału dochodu, czyli dystrybucji, uznał, że wymowa doktryny konfucjańskiej nie jest liberalna, ale - w tym wąskim aspekcie socjalizująca. Z drugiej strony poprawnie odczytany konfucjanizm - jako całość, nie w jakimś tylko aspekcie - reprezentuje ten socjalizujący sposób widzenia świata, gospodarki i jej systemowej organizacji.

Ze względu na rozmach reform rosną wątpliwości, czy nie spowodowały one, że Chiny utraciły swój socjalistyczny - konfucjański - charakter. Na szczęście ustalenie, czy obecny system gospodarczy w Chinach jest socjalizmem czy kapitalizmem, nie jest tylko ćwiczeniem logicznym. Możliwe jest rozwiązanie tego problemu na podstawie faktów. Praca amerykańskiego ekonomisty Barry'ego Naughtona jest bardzo cenna pod tym względem ${ }^{15}$. Jego zdaniem obecne Chiny są ciągle socjalistyczne - nastąpiła tylko zmiana formy socjalizmu z nakazowego na rynkowy. Socjalizm zakłada, że dla realizacji zasad socjalistycznych (lub zobowiązań moralnych) państwo musi mieć duży udział w zasobach kapitałowych i innych. Aktualnie ten udział jest nadal bardzo duży, w każdym razie wystarczający do skutecznych interwencji. W obecnych Chinach głównym źródłem dochodów państwa jest podatek od towarów i dochodów przedsiębiorstw państwowych. Udział dochodów budżetowych w dochodzie narodowym w 1996 r. wynosił 14\%, by w 2015 r. wzrosnąć do 37\%, czyli się potroić. Co ważne, państwo utrzymało dominujący udział własnościowy - władze nigdy nie zaakceptowały prywatyzacji gospodarki. W głównych sektorach, w tym w bankach i ubezpieczeniach, dominują publiczne firmy. Wysokie udziały koncentrują się też w kapitałochłonnych gałęziach przemysłu (np. węgiel, stal). Ważny jest fakt, że zgodnie z najnowszymi programami władz - pod kierunkiem $\mathrm{Xi}$ - Chiny są zdecydowane utrzymać model wielowłasnościowy, w którym główna część pozostaje własnością publiczną, i to na stałe.

Socjalizm w wersji nakazowej stał się przeszłością, ale w jego obecnej, rynkowej wersji nastąpił daleko idący wzrost rozbieżności w dochodach. Współczynnik Giniego wzrósł z 28 w 1978 r. do 46 w 2015 r. i zbliżył się do przedziału raportowanego w głęboko rozwarstwionej Ameryce. Jednak ze względu na pewne szczególne rozwiązania Chiny są nadal stosunkowo egalitarne. Jednym z mechanizmów wyrównywania różnic jest polityka

14 H. Chen, op. cit.

15 B. Naughton, Is China Socialist?, „The Journal of Economic Perspectives” 31/1/ 2017. 
utrzymania parytetu dochodów miejskich i wiejskich. Państwo zapewnia obecnie 70 milionom ludzi minimalne dochody i świadczenia, włącznie z bezpłatnym leczeniem. W 1989 r. było 260 milionów ubogich, w 2015 56 milionów ${ }^{16}$. Co więcej, bogaci muszą się dzielić swymi dochodami w drodze specyficznej dla Chin „konsumpcji społecznej”. W jej ramach muszą budować na swój koszt bezpłatne drogi, muzea i tak dalej. A ostatnio muszą finansować, i to na wielką skalę, ochronę zdewastowanego środowiska. Miliarderzy chętnie wykonują nakazane przez partię (państwo) programy publiczne, ponieważ bez dostępu do władzy kapitanowie przemysłu są tak naprawdę na łasce jego administratorów.

Jak naucza konfucjanizm, państwo ma ważną pozytywną rolę do odegrania, ale pod warunkiem, że jest to „moralne” państwo, to znaczy nieskorumpowane. Można sobie wyobrazić gospodarkę bez - nazwijmy to - „publicznej” (w przeciwieństwie do „prywatnej”) - korupcji poprzez usunięcie państwa. Ale jest to nieosiągalne, ponieważ podobnie jak rynek, państwo jest wieczną instytucją lub społecznym wynalazkiem. Jedynym praktycznym rozwiązaniem jest zapewnienie, że ludzie u władzy szanują interes społeczny. Dla powodzenia gospodarki, oprócz edukacji lub wiedzy, niezbędna jest przede wszystkim integralność. Oznacza to między innymi, że państwo nie ingeruje w sprawy, które mogą być lepiej uregulowane przez jednostkę, a raczej rodzinę. W wersji konfucjańskiej takie państwo moralne ma za główny cel wykluczenie monopoli poprzez opodatkowanie wszystkich dochodów z dzierżawy, pochodzących ze spekulacji podażowych, jako niezasłużonych zysków. Ludzie potępiają takie czynsze jako niemoralne. To dlatego monopole w produkcji są głównym źródłem politycznej destabilizacji - jako potencjalnie największego zagrożenia dla gospodarki, czyli bogactwa narodowego.

\section{Przedmiot badań}

Szukając najbardziej akceptowalnego paradygmatu, zachodni uczeni poruszają się ciągle pomiędzy jednostką i państwem jako głównymi aktorami. Walcząc ze sobą o prymat w ekonomii, skłóceni naukowcy nie zauważyli jednak, że w ciągu kilku wieków wyrządzili szkody innemu, potencjalnie znaczącemu graczowi. Tą w zasadzie uboczną ofiarą zachodnich kontrowersji lub, ściślej, rewolucji (nazwijmy ją liberalną) okazała się instytucja

\footnotetext{
16 Por. ibidem.
} 
rodziny. Diagnoza ta najlepiej oddaje istotę systematycznej ewolucji myślenia ekonomicznego, która dokonywała się w ciągu ostatnich dziesiątków lat na Zachodzie. Pojedynek ten skończył się prawie całkowitym zwycięstwem liberałów, niemniej w ostatecznym rachunku zmiana w postrzeganiu roli rodziny okazała się źródłem porażki liberalizmu. Powodem było to, że rodzina nie jest jedyną ofiarą tej ewolucji, drugą bowiem jest jednostka jako w pełni samodzielny aktor. Zadaniem liberalizmu jest ochrona jednostek przed nadużyciami ze strony państwa lub Kościoła (religii). Jednakże pozbawiona wsparcia ze strony swej rodziny, pozostawiona sobie jednostka staje się jeszcze bardziej bezbronna wobec zakusów aparatu państwa. Innymi słowy, żeby wzmocnić rolę jednostki, trzeba wzmocnić rodzinę jako instytucję, tymczasem dokonało się coś przeciwnego.

Paradoksalnie wymierzony programowo przeciw państwu liberalizm doprowadził do tego, że jedynym zwycięzcą w procesie modernizacji okazało się właśnie państwo. Obraz staje się bardziej zróżnicowany, jeśli weźmie się pod uwagę równoległe zmiany w roli Kościoła. U swych źródeł - jak wspomniałem - liberalizm wziął się nie tylko z deklarowanej troski o uwolnienie jednostek od nadużyć władzy państwa, ale również z obietnicy wyrwania jednostek spod wpływów religii w drodze tak zwanej sekularyzacji. Liberalizm wygrał pojedynek z Kościołem, jednakże w konsekwencji osłabła rola rodziny, symbiotycznie związanej z religią. Jest oczywiste, że w tym przypadku nie chodzi o marginesowe zmiany, ale o „tektoniczne przesunięcia”, z kolosalnymi skutkami. Można więc spekulować, że ta opisana tutaj - wielowymiarowa - transformacja światopoglądowa może leżeć u podstaw szeroko rozpatrywanej obecnie kwestii kryzysu intelektualnego w świecie zachodnim, szczególnie w głównym nurcie liberalnej ekonomii. Wyniki gospodarcze nie dają podstaw do twierdzenia, że będąc źródłem cudu gospodarczego, chiński konfucjanizm też przeżywa kryzys zbiorowej świadomości swoich wyznawców. Mamy więc dwa światy, czy raczej bloki cywilizacyjne: jednym jest niespokojny zachodni świat współczesnego liberalizmu, a drugim - kwitnący starożytny konfucjanizm Chin.

Zachodni świat narażony jest na kryzysy, gdyż boryka się ze swoimi niedopracowanymi, czy wręcz błędnymi założeniami. Aby sprawdzić realizm liberalnej ekonomii, proponuję następującą metodę. Najpierw ustalmy listę głównych liberalnych założeń związanych z ekonomią, przede wszystkim z zaangażowaną gospodarczo jednostką, a potem sprawdźmy, w jaki sposób działałyby one, gdybyśmy skonstruowaną przez liberałów autonomiczną, racjonalną, samodzielną jednostkę zastąpili rodziną jako głównym podmiotem. Zaletą takiego testu stawiającego rodzinę na pierwszym miejscu 
jest oczywiście to, że wszyscy ludzie mają rodziny. Powinno to wystarczyć do sprawdzenia, jak to liberalne założenie, że jednostki są autonomiczne, zadziałałoby, gdyby liberalna jednostka została zastąpiona przez rodzinę. Odpowiedź brzmi: samowystarczalna osoba to fikcja. Fakt, że większość ludzi żyje w rodzinach, jest dostatecznym dowodem tego, że ludzie potrzebują siebie nawzajem. I to nie pod przymusem, ale choćby ze względu na samą potrzebę wspólnoty. To wyjaśnia, dlaczego ludzie spędzają większość czasu w otoczeniu członków rodziny i krewnych. W rzeczywistości Chiny są przykładem wyjątkowej bliskości czy intymności stosunków, czego dowodem może być architektura. Tradycyjnie domy są projektowane bez ścian wewnętrznych, jedynie z ruchomymi przegrodami. Pomieszczenia mieszkalne otwierają się w stronę kwadratowego dziedzińca, dzięki czemu wszystkie ruchy mieszkańców są widoczne.

Czy jest jakieś inne liberalne założenie na temat funkcjonowania świata, które mogłoby się sprawdzić po zastąpieniu jednostki rodziną jako przedmiotem analizy? Z pewnością warto by się przekonać, czy w odniesieniu do rodziny można przeprowadzić test liberalnego przekonania, że ludzie zawsze stoją w obliczu niedoboru zasobów. Jeśli, jak twierdzą liberałowie, niedobór występuje na poziomie zagregowanym, czyli społeczeństwa, to musi być obecny również w rodzinach, które tworzą taki agregat. Wynikałoby z tego, że zasoby pod kontrolą rodziny także nie wystarczają do utrzymania wszystkich jej członków przy życiu. Musiałyby się też ujawnić wszystkie negatywne konsekwencje takiej sytuacji. Dla liberałów główną konsekwencją w skali ogólnej jest tak zwana nadwyżka populacji. Jeśli tak, to ten sam problem powinien być doświadczany również w rodzinie. Ponieważ według założeń liberalnych w gospodarce nie ma miejsca na etykę, aby przywrócić niezbędną równowagę, jak uczą Malthus lub Hobbes, część rodziny musiałaby zostać wyeliminowana, zagłodzona lub zwyczajnie uśmiercona. Interesującym pytaniem byłoby, kto w rodzinie miałby zadbać o powrót do, liberalnie rozumianej, równowagi. Dla jasności należy dodać, że poza stronami liberalnej literatury nie ma, oczywiście, żadnych śladów czegoś podobnego i równie przerażającego.

Kolejnym poligonem doświadczalnym jest dystrybucja produkcji lub dochodu. Jak wspomniałem, dla liberałów dystrybucja jest funkcją tego, co ludzie wnoszą do produkcji. Innymi słowy, oczekuje się, że alokacja będzie proporcjonalna do indywidualnej wydajności. Z tym nieuchronnie wiąże się nierówność dochodowa, ale, jak twierdzą liberałowie, nierówność jest korzystna dla wydajności. Nie tak jednakże działa realny świat, jeśli chodzi o dystrybucję dochodu. Większość produkcji jest dzielona w ramach rodziny, 
a nie przez pojedynczych konsumentów - w rzeczywistości większość tego, co jest produkowane w dowolnej gospodarce, jest rozprowadzane przy stole rodzinnym. Jak jednak wyglądałby ten podział, gdyby przestrzegano zasad liberalnych, czyli rozdzielenia według indywidualnego wkładu? Dzieci i osoby starsze zostałyby, oczywiście, bez żadnych środków. Oto więc część rodziny, czyli pracujący i zarabiający pieniądze, miałaby pełne talerze, a reszta, niepracująca i bez pieniędzy, dostałaby - na oczach całej rodziny - okruchy lub nic. Ludzie wiedzą jednak z własnego doświadczenia, że w rodzinie jedzenie jest dzielone przy wspólnym stole stosownie do potrzeb jej członków. Dzieje się tak dlatego, że jedzenie nie służy temu, żeby zjeść jak najwięcej, ale aby utrzymywać się w dobrym zdrowiu. Tak przynajmniej postępują racjonalni, lub lepiej - rozsądni ludzie.

\section{Problem niedoboru}

Jak to możliwe, że pełen wątpliwych założeń liberalizm był w stanie rzucić skuteczne wyzwanie światopoglądom socjalizującym, koncentrującym się na etyce i rodzinie? Przecież w prawdziwym życiu ludzie stale odczuwają ciężar etycznych powinności, z ich źródłami tkwiącymi w rodzinie. Ten zabieg okazał się skuteczny głównie dlatego, że liberałowie wprowadzili prosty i bardzo chwytliwy slogan, czyli „rzadkość”. W jakimś sensie to jest najważniejsze założenie doktryny liberalnej. Powtórzmy: według tej koncepcji jednostki, jako istoty racjonalne, nieprzerwanie znajdują się w sytuacji nieograniczonych potrzeb i ograniczonych dostępnych zasobów. Można się tylko zastanawiać, jak osoba ze wszystkimi racjonalnymi odruchami mogłaby potraktować poważnie taką przerażającą i żałosną wizję świata. Dokonując tych arbitralnych założeń, liberałowie zastawili pułapkę na samych siebie. Jeśli bowiem jednostki są racjonalne w sensie liberalnym i wiedzą wszystko, na pewno nie mogłyby działać przeciwko sobie. Racjonalna osoba z pewnością nie opowiedziałaby się za tego rodzaju wizją świata, gdyż oczywiście pogoń za, skądinąd iluzoryczną, bezgraniczną konsumpcją dóbr materialnych prowadziłaby jedynie do bolesnej frustracji. Nie mówiąc o tym, że jednostka taka musiałaby się zorientować w jakimś momencie, iż aby zaspokoić niekończące się potrzeby, potrzebowałaby na przykład nieograniczonych fizycznych możliwości trawienia żywności.

Pamiętając, że ogólnie mówiąc, „niedobór zasobów” wyklucza moralność, można zidentyfikować inną jeszcze pułapkę. Dotyczy ona posiadania dzieci, gdyż popyt na dobra zależy od liczby potomstwa. Im jest go więcej, 
tym większe potrzeby ma rodzina, a więc i większe zapotrzebowanie na zasoby. To zapotrzebowanie jest - zdaniem wczesnych liberałów - nieograniczone, nieograniczony zatem musi być popyt na dobra, a więc i zasoby. Kiedy klasyczni myśliciele - tacy jak Hobbes czy Malthus - mówią o nadmiernym popycie na zasoby, mają na myśli między innymi to, że ponoć z natury ludzie przeznaczają wszystkie dodatkowe przyrosty produkcji na prokreację. Wspomniani ekonomiści skarżą się w swych pracach, że zamiast rezygnować z indywidualnej konsumpcji i inwestować dodatkowe pieniądze, aby zarobić jeszcze więcej, ludzie przeznaczają te przyrosty w całości na powiększanie rodziny. Zakładana racjonalna jednostka nie wybierze jednak takiej strategii. Trudno uwierzyć, że biorąc pod uwagę zgromadzone doświadczenie, ludzie nigdy nie będą w stanie się zorientować, kiedy powinni przestać powiększać swoją rodzinę. Muszą w końcu zrozumieć, że decydując się na więcej dzieci, biorą na siebie ryzyko, iż od pewnego momentu każdy noworodek będzie musiał być narażony na pogarszające się warunki życia.

Ale nawet jeśli pojęcie nieograniczonych potrzeb zostanie usunięte z ogólnego równania, liberałom wystarczy stan „ograniczonych zasobów”, żeby pojawiła się „nadwyżka populacji”, wraz z jej wszystkimi brutalnymi skutkami. To pojęcie ograniczeń fizycznych - w zasobach - nie jest sensowniejsze niż właśnie zakwestionowany pomysł „nieograniczonych potrzeb”. Intuicyjnie wydaje się całkowicie niewiarygodne, że powszechnie, w każdej chwili i w każdym miejscu, natura zmusza ludzi do tak brutalnej egzystencji, iż życie na ziemi to - by tak rzec - piekło na ziemi. Ten argument na temat uniwersalności niedoboru jest po prostu niewiarygodny. Jeśli niedobór jest uniwersalny, w rzeczywistości nie pozwalałby na rozpoczęcie życia. Przy liberalnym założeniu, że niedobór zasobów jest powszechny, „nadwyżka populacji” musiałaby bowiem być również uniwersalna. W związku z tym zrozumiałe jest, że już pierwsi ludzie na ziemi musieliby przywracać równowagę poprzez eliminację tej nadwyżki. Trudno uwierzyć w to, że od samego początku egzystencji miałyby dominować głód i zabójstwa, skoro pierwsi ludzie - nieliczni pierwotni mieszkańcy - mieli dla siebie całą planetę, by zaspokoić swoje materialne potrzeby.

Powyższa tradycyjna pozycja liberalna nadal dominuje - z godnymi uwagi wyjątkami. Na przykład Paul Romer stwierdził, że zachodnia ekonomia jest zbudowana na wyjątkowo chwiejnych fundamentach. Prawie 25 lat temu zakwestionował liberalne pojęcie niedoboru, wyrażone w mikroekonomicznej koncepcji rosnących kosztów (lub spadających zysków). Użył statystyk międzynarodowych, aby pokazać, że z czasem tempo wzrostu 
gospodarczego na świecie rośnie tak, jakby nie było żadnych ograniczeń w zasobach. Na tej podstawie opracował teorię wzrostu endogenicznego. Jak widać, odrzucił pojęcie niedoboru, choć tylko częściowo. Wyjaśnił, że fizyczne zasoby są istotnie ograniczone, ale nie wiedza jako czynnik produkcji. Jako najważniejszy zasób wiedza się nie zużywa, w przeciwieństwie do zasobów fizycznych. Im więcej się jej używa, tym więcej jej przybywa. Szersze jej zastosowanie powoduje spadek kosztów krańcowych. Takie ograniczone odejście to było zbyt wiele dla liberałów, aby mogli zaakceptować jego pogląd i wprowadzić myślenie w ramach głównego nurtu ekonomii na etap, który najlepiej nazwać „ekonomią obfitości”. Odnosząc się do tej porażki, w swoim ostatnim ataku na metodę współczesnej ekonomii Romer oskarżył ekonomistów, że nie dbają o fakty, ale o znajomych, to znaczy o ich ściśle powiązane kliki ${ }^{17}$.

\section{Korzyści konfucjańskie}

Solidna gospodarka wywodzi się z właściwego myślenia, czym są zatem szczególne korzyści z przyjęcia perspektywy Konfucjusza? Na początek można wysunąć argument, że zastąpienie „natychmiastowej gratyfikacji” jako głównego celu dążeń ciągłością trwania rodziny musi być korzystne. Trzeba zauważyć, że takie przekonanie, jeśli chodzi o cele i wybory jednostki, wpływa na przyjęty horyzont czasowy. Pojedyncza osoba działa, powiedzmy, z jednodniowym horyzontem lub, co najwyżej, w ramach czasowych nie dłuższych niż długość życia. Osoba motywowana zachowaniem ciągłości linii rodzinnej poprzez prokreację działa natomiast w zasadzie w nieskończonym horyzoncie czasowym. Wychodzi w swej analizie dostępnych opcji głęboko w przyszłość, i tak pokolenie po pokoleniu. Przy dłuższym horyzoncie czasowym jednostki są bardziej skłonne do oszczędzania zarobionych pieniędzy i inwestowania więcej, co jest oczywiście korzystne dla wzrostu gospodarki. Fakt, że Chiny działają z innym poczuciem wartości bieżącej, które wyjątkowo sprzyja inwestycjom, jest niekwestionowalny. Przykładowo, stopa inwestycji w Chinach wynosi dzisiaj 45-50\% rocznie, czyli dwukrotnie więcej niż 20-25\%, które uważa się w ekonomii za teoretycznie wystarczające do trwałego wzrostu w średnio rozwiniętych gospodarkach, takich jak chińska.

17 P. Romer, The Origins of Endogenous Growth, „The Journal of Economic Perspectives” 8/1/1994. 
Jak już powiedziałem, zdaniem liberałów niedostatek sprawia, że gospodarki nie są w stanie wyżywić wszystkich ludzi w jakimkolwiek momencie, pojawia się więc związane z tym pytanie, co może być korzyścią płynącą z odrzucenia tego założenia i zastąpienia go perspektywą konfucjańską, w której zamiast niedostatku panuje obfitość. Dla liberałów nie jest to łatwy eksperyment, ponieważ bez zaakceptowania pojęcia niedostatku traci sens liberalna ekonomia. Co ważne, zaakceptowanie idei obfitości eliminuje racjonalne uzasadnienie prymatu rywalizacji (konkurencji). W warunkach obfitości powstaje jednak szansa na „luźny harmonogram”, w którym dozwolone są pewne straty zasobów. Ułatwia to absorpcję nieuniknionych strat związanych z wprowadzaniem innowacji. W ten sposób okazuje się, że chińska postawa musi przynosić korzyści w formie większej liczby innowacji, które - jak podkreśla Schumpeter - są najważniejszym atrybutem rynków. Nic dziwnego, że Chiny były wiodącym innowatorem w przeważającej części historii świata. Zostało to udokumentowane w monumentalnym badaniu brytyjskiego sinologa Josepha Needhama ${ }^{18}$. W tej historycznej roli mają one na koncie większość kluczowych technologii, których Wielka Brytania potrzebowała, aby ostatecznie rozpocząć swoją rewolucję przemysłową ${ }^{19}$.

Inną korzyść płynącą z konfucjanizmu można zidentyfikować, analizując preferowaną strategię zwiększania bogactwa, którą dla wierzących w niedobory liberałów jest przejęcie niezbędnych zasobów fizycznych od innych (np. poprzez konkurencję, z dopuszczalnym bankructwem). Z drugiej strony ekonomiści konfucjańscy, z ich wiarą w obfitość, twierdzą, że gospodarka polega na efektywnym wykorzystaniu zasobów, a konkretnie pracy. To, że zasoby są nadmierne, nie oznacza, iż nie ma problemu wyboru. Dla nich problem ekonomiczny polega na najbardziej opłacalnym wykorzystaniu zasobów pracy. Dlatego najlepsza strategia to ta, która najsilniej mobilizuje siłę roboczą. Dla ścisłości wypada dodać, że najważniejsza dla wyników ekonomicznych jest etyka pracy. Koncentrując się na jakości pracy, a nie na ilości zasobów, konfucjanizm wydaje się przeważać nad liberalizmem. Dzieje się tak dlatego, że bogactwo bierze się głównie z pracy, która dla konfucjanizmu jest przedmiotem kultu, a dla liberalizmu nie. Zgodnie z poglądem liberalnym praca jest udręką, dzieje się kosztem wypoczynku, jej celem jest zapracowanie na to, żeby nie pracować. Natomiast konfucjaniści mówią

${ }_{18}$ J. Needham, Science and Civilization in China, vol. 2: History of Scientific Thought, Cambridge University Press, Cambridge 1956.

19 J. Hobson, Eastern Origins of Western Civilization, Cambridge University Press, Cambridge 2004. 
o radości wynikającej z pracy. W chińskim systemie ludzie nie lubią bezczynności, nienawidzą lenistwa, co dodatkowo wyjaśnia, dlaczego pracują przez całe życie, dostosowując zadania odpowiednio do wieku.

Kolejną kwestią jest charakter motywacji, zastąpienie praw własności jako źródła motywacji, za czym opowiadają się liberałowie, konfucjańskim naciskiem na „uczucia moralne”. Dla liberałów te ostatnie są zagrożeniem dla racjonalności, czyli optymalnych wyborów. Praktycznie nieobecna w podejściu liberalnym etyka jest wspominana przez ekonomię neoinstytucjonalną, której głównym przedstawicielem jest Douglass North ${ }^{20}$. Jej centralną ideą jest rozróżnienie kosztów produkcji i kosztów transakcji, czyli kontraktu. Z kolei dla konfucjanistów moralność ma znaczenie, ponieważ pomaga obniżyć koszty transakcyjne związane z wykonywaniem umów prawnych. Im niższe koszty transakcji, tym niższa cena produktu i tym wyższy zysk. W ekonomii konfucjańskiej wspomniane są również prawa własności. Konfucjaniści różnią się jednak od liberałów pod względem preferowanych sposobów obniżenia kosztów transakcji. Oba systemy podkreślają zalety obniżania kosztów zawieranych umów, ale konfucjaniści idą znacznie dalej. Uważają, że prawo jest całkowicie niepotrzebne do prowadzenia działalności gospodarczej. Ich ideałem jest wyeliminowanie potrzeby procesów sądowych. Zgodnie z zasadą konfucjańską, aby utrzymać koszty na niskim poziomie, umowy nie są zawierane głównie przez państwo, lecz przez rodziny i klany, a więc nieformalnie. To wyjaśnia, dlaczego koszty obsługi prawnej w Chinach (także w Japonii ${ }^{21}$ ) są ułamkiem tego, co jest normą w ciągle procesującym się biznesie zachodnim.

Przechodząc do kolejnej kwestii, można postawić pytanie o wpływ wyboru preferowanej formy regulacji społecznej. Jeśli moralność jest kluczem do zarządzania bogactwem, to główną formą organizacji musi być jej źródło. Jak wspomniałem wcześniej, dla konfucjanistów jest nim nie rynek, ale rodzina. Aby właściwie funkcjonować, rynek musi być osadzony w moralności, z jej rodzinnymi korzeniami. Górować musi doktryna, która kładzie nacisk nie na dostarczanie fizycznych dóbr na rynku towarów, ale na dostarczanie wartości moralnych w strukturach rodziny. Umieszczenie przez konfucjanistów rodziny na pozycji głównej formy organizacji gospodarki musi zatem

${ }^{20}$ D. North, Structure and Change in Economic History, Norton \& Norton, New York 1981.

21 Por. J. Haley, The Japanese Judiciary: Maintaining Integrity, Autonomy, and the Public Trust, w: D. Foote (red.), Law in Japan: A Turning Point, University of Washington Press, Seattle 2008. 
być korzystne. Sprawia to, że jednostka na „wolnym rynku” jest słabszym ogniwem aniżeli rodzina. Można oczekiwać, że chińska gospodarka będzie się składać głównie z małych firm rodzinnych. Jednym z przykładów takiego efektu skali jest gromadzenie oszczędności przez rodzinę, a tym bardziej przez klany. Wydaje się, że cud gospodarczy Chin został sfinansowany głównie właśnie dzięki poleganiu na rodzinie. Można dodać, że ta preferencja dla małych biznesów jest w rzeczywistości dość powszechna w innych krajach, nawet w rozwiniętej Europie, na przykład w Niemczech, gdzie obejmują one 4 miliony osób i stanowią podstawę powojennego niemieckiego cudu.

\section{Opcje zachodnie}

Ponieważ różnica między kwitnącym dziś konfucjanizmem a osłabionym obecnie liberalizmem dotyczy postaw wobec moralności i rodziny jako jej źródła, konfucjańską receptą na przezwyciężenie kryzysu na Zachodzie byłby w pierwszej kolejności postulat przywrócenia tych dwóch zmiennych niezależnych w analizie ekonomicznej. Ponieważ zastąpienie liberalizmu konfucjanizmem nie jest realne, możliwego leku należy szukać we własnej intelektualnej tradycji Zachodu. Trzeba pamiętać, że obecny liberalizm - jako podstawa kapitalizmu - jest tylko etapem w jego ewolucji. Jego początki różnią się od fazy rozkwitu, która z kolei różni się od obecnego stadium zwątpienia, czyli neoliberalizmu. Oczywiście, nie chodzi tu o utrzymywanie neoliberalizmu, który jest agnostyczny lub nihilistyczny i promuje skrajny indywidualizm. Protoliberalizm z wczesnej fazy jest bardziej przydatną częścią zachodniej tradycji. W grę wchodzi pierwsza generacja klasyków, dla której ekonomia była filozofią moralną. Należą do tego pokolenia głównie przedstawiciele tak zwanego szkockiego oświecenia. Do tej grup zalicza się wczesny Adam Smith z jego słynnym krótkim traktatem Teoria uczuć moralnych (1759).

Na początkowym etapie swej naukowej kariery Smith uważał, że gospodarka jest regulowana przez moralność. Głównym motywem jednostki jest zdobycie uznania społecznego czy prestiżu. Drogą do tego jest identyfikowanie się z potrzebami i problemami innych, ponieważ w ten właśnie sposób zyskuje się uznanie społeczne. Liberalizm szybko jednak wyzbył się tego wymiaru etycznego. Sam Smith odegrał główną rolę w owym odwrocie. Wprowadził różne „rewolucyjne” koncepcje niezwiązane z etyką. Jedną z nich jest tak zwany podział pracy. Był to postęp w zrozumieniu, jakie są prawdziwe źródła bogactwa narodowego, ponieważ dzięki specjalizacji koszty produkcji są obniżane. Można się z tym zgodzić, ale ta koncepcja nie jest bez skazy. 
Jak należy wnioskować, podział dotyczy produktów, a nie ról społecznych. W praktyce najważniejszy podział dotyczy ról, w tym mężczyzn i kobiet (czy ojca i matki). Oczywiście, cała rodzina jest podstawową - ale nie jedyną - formą organizacji. Według antropologów postęp społeczny rozpoczął się (lecz nie zakończył), kiedy mężczyźni zajęli się polowaniem, a kobiety zbieractwem.

Istnieje również problem z drugą nową koncepcją wprowadzoną przez Smitha w późnym okresie jego działalności, a mianowicie wizualizacją instytucji rynkowej jako „niewidzialnej ręki”. Jest to układ pozbawiony osobistych relacji między uczestnikami. Ludzie zachowują się jak pozbawione uczuć maszyny. Nie reagują na to, co inni myślą czy robią, ale tylko na sygnały rynkowe, to znaczy określone przez popyt i podaż ceny. Zakłada się, że takie ceny rynkowe gwarantują racjonalność ekonomiczną. Prawda jest taka, że ludzie kierują się głównie rutyną. Wielokrotnie wypróbowywane i sprawdzone w działaniu procedury stają się drugą naturą człowieka. Nie jest jednak możliwe, aby podstawowym instynktem ludzkim była chęć uczestniczenia w rynku, produkcja na sprzedaż i pomnażanie zysku. W rzeczywistości drugą naturę człowieka stanowi odruch moralny. Moim zdaniem to moralność jest prawdziwą niewidzialną ręką. Nie ma przed nią ucieczki, ponieważ człowiek nabywa jej spontanicznie, podobnie jak umiejętności posługiwania się językiem. Zarówno język, jak i moralność stają się właściwym tworzywem człowieka.

David Ricardo, jako kolejny ojciec liberalizmu, stworzył dwie koncepcje. Jedna to teoria rosnących kosztów lub malejących przychodów. Jest to wyrafinowane odzwierciedlenie podstawowej idei niedoboru (czy rzadkości) zasobów. Na ten temat miał on do opowiedzenia swoją własną - całkiem przekonującą - historię. Jego zdaniem istnieje stała ilość gleby nadającej się do uprawy. Ziemia nie jest przy tym jednolita, ale ma różne poziomy płodności. Gdy populacja ludzi rośnie, potrzeba więcej żywności, a zatem trzeba wykorzystać więcej ziemi. Producenci nie mają innego wyboru jak przenieść się z bardziej żyznych na mniej żyzne działki. Ponieważ jest coraz mniej urodzajnych gruntów, trzeba płacić więcej, tak że cena żywności rośnie. Jest to zysk dla właścicieli gruntów i strata dla producenta, a ostatecznie dla konsumenta. Ricardo ogłosił, że należy przewidywać, iż standard życia ogółu pogorszy się. Podczas gdy wspominany już Malthus martwił się, że robotnicy będą się obsesyjnie rozmnażać, Ricardo ostrzegał, że właściciele ziemscy połkną produkt narodowy ${ }^{22}$. Ale to się

${ }^{22}$ Por. T. Piketty, Capital in the Twenty-First Century, Harvard University Press, Harvard 2014. 
nie wydarzyło i - jak na ironię - w tym czasie, gdy Ricardo pisał swoją pesymistyczną teorię, trwała rewolucja przemysłowa, która podwoiła tempo wzrostu gospodarczego. To wystarczający powód do optymizmu.

Za tym pesymistycznym argumentem - typowym dla pesymistycznego liberalizmu - podąża kolejny słynny argument Ricarda, tyle że tym razem jest on optymistą. Jest to teoria handlu zagranicznego, zwana teorią przewagi komparatywnej. To, co oferuje, jest niemal magiczne, obiecuje bowiem wzrost wartości produkcji przy tych samych zasobach fizycznych, tutaj - pracy. Innymi słowy, zapowiada czysty zysk, czekający tylko na to, aż zostanie zebrany. Dołączony do tej teorii jest model dla dwóch krajów oraz dwóch produktów. Jeden z tych krajów ma niższe koszty jednostkowe na obu dobrach będących przedmiotem wyboru. Ta sytuacja powinna wykluczyć jakikolwiek handel, chyba że względne koszty (i ceny) są różne. Wtedy nawet kraje o nierównomiernym poziomie rozwoju mogą zyskać na handlu. I nie ma obawy, że jeden z nich - prawdopodobnie bardziej rozwinięty - zbierze wszystkie zyski z handlu. Stanie się odwrotnie, gdyż, zdaniem Ricarda, zostaną one równo podzielone między uczestników wymiany. Tymczasem prawda jest taka, że handel zagraniczny to tylko przewóz towarów, nie może więc sam z siebie być źródłem wartości. Handel polega na tym, że pośrednik - jako dostawca towarów - po prostu dodaje koszty przesyłki i odpowiednio zwiększa cenę (taki argument podnosi Paul Krugman $^{23}$ ).

Powrót do protoliberalizmu - z uwzględnieniem komentarzy wczesnego Smitha - może być sposobem na odnowienie zachodniej ekonomii. Jak zauważyłem wcześniej, taki wysiłek został już podjęty w latach trzydziestych XX w. Myślę o pracach Schumpetera i szkoły austriackiej. W tym podejściu kapitalizm traktuje się jako produkt moralności. Powstał on wraz z pojawieniem się klasy przedsiębiorców lub, inaczej, burżuazji. Ta nowa klasa przyniosła z sobą nową potężną motywację ekonomiczną - jej własną burżuazyjną moralność. Klasa ta charakteryzuje się obsesyjnym zainteresowaniem oszczędnościami przeznaczanymi na inwestycje oraz wyjątkowym pędem do technicznych innowacji. Tak więc widzenie kapitalisty jako pasożytniczego, niemoralnego osobnika jest fikcją. Kapitalista faktycznie „zarabia” na swoje utrzymanie i nie dzieje się to niczyim kosztem. Jednocześnie rzeczywistym podmiotem działalności właścicielskiej nie jest jednostka jako taka, ponieważ przedsiębiorcy działają jako członkowie rodziny. Podmiotem

23 Por. P. Krugman, A. Venables, Globalization and the Inequality of Nations, „The Quarterly Journal of Economics” 110/4/1995; zob. też K. Poznanski, Confucian Economics... 
w istocie jest zatem rodzina, z żoną i matką, w której wszyscy wykonują swoją pracę - i ponoszą ryzyko - dla bliskich z zamiarem zbudowania czy utrzymania własnej dynastii.

Według Schumpetera problem z kapitalizmem zaczyna się nie wtedy, gdy państwo (i jego działalność) wypiera rynek, jak to się dzieje w wizji marksistowskiej, ale gdy zmienia się charakter rodziny, ściślej mówiąc, gdy ginie jej burżuazyjny etos. Upadek kapitalizmu nie jest konieczny, lecz jest możliwy, gdy troskę o interes rodziny, przedsiębiorcy, społeczeństwa zastąpi się troską o innych przez zimną kalkulację własnych korzyści. Są też inne czynniki, zwłaszcza transformacja ,agresywnego inwestora” (i „przedsiębiorczego innowatora”) w rentierów zarabiających pieniądze na finansowych operacjach. Schumpeter mówił o swoich czasach, ale wielu jego zwolenników uważa dzisiaj, że wizja, którą oferował w duchu protoliberalnym, może być przydatna do analizowania także obecnych, jak sądzą, przejawów kryzysu kapitalizmu. Warto zauważyć, że ten rodzaj analizy, odchodzący od neoliberalizmu, jest w różnych miejscach zbieżny z konfucjańskim sposobem myślenia etycznego, z jego naciskiem na moralność i rodzinę.

\section{Polityka zasług}

Obecny cud gospodarczy Chin nie jest końcem pasma chińskich sukcesów. Cieszą się one dwoma niezwykłymi osiągnięciami: jednym jest cud gospodarczy, a drugim cud polityczny. Możemy zatem mówić o podwójnym cudzie. Jakie są symptomy osiągnięć na niwie politycznej? Przed rozpoczęciem reform gospodarczych w 1978 r. Chiny przechodziły trudny okres związany z eksperymentami „wielkiego skoku”, a potem z chaosem rewolucji kulturalnej. Starcia wewnątrzpartyjne znacznie uszczupliły możliwości działania państwa. To, że Chiny były w stanie sprawnie opanować oba kryzysy, samo w sobie jest niezwykłe. Co więcej, zdążyły jeszcze skutecznie przeprowadzić masowe reformy gospodarcze. W związku z niesamowitym tempem wzrostu można było oczekiwać, że zaczną jednocześnie przechodzić poważne przemiany na scenie politycznej, a przy tej okazji mogą zaistnieć nawet jakieś polityczne przetasowania czy wstrząsy. W zasadzie nic takiego się nie wydarzyło. Z powodu gwałtownych zmian strukturalnych w produkcji miliony ludzi straciły pracę w sektorze państwowym, ale nie doszło do znacznych strajków. Nastąpił ogromny odpływ siły roboczej do miast, który jednak nie wywołał politycznej reakcji. Także nierówność dochodów gwałtownie wzrosła, co nie spowodowało zauważalnych niepokojów 
społecznych. Widoczne oznaki niezadowolenia wśród ludności ograniczają się właściwie do sporów o ziemię między rolnikami i deweloperami.

Jeśli założymy, że stabilność warunków politycznych jest właściwym wskaźnikiem cudu politycznego, powstaje pytanie, co tak naprawdę stało się z chińskim ustrojem od czasu, gdy gospodarka wyraźnie przyspieszyła. Reformy gospodarcze z pewnością wymagały reform politycznych. W sferze politycznej sytuacja postrzegana jest jednak inaczej - dominuje pogląd, że reformy gospodarcze były dalekosiężne w przeciwieństwie do politycznych. Mówi się więc, że podobnie jak w przeszłości, to polityka dominuje w gospodarce. Modus operandi partii też się nie zmienił. Cechą charakterystyczną tego typu upolitycznionej gospodarki były kampanie partii, czyli sporadyczne mobilizacje emocji społecznych uruchamianych z myślą o realizacji radykalnych programów, takich jak polityka jednego dziecka ${ }^{24}$. To dziedzictwo kampanii ciągle trwa. Reformy polityczne przyniosły jednak pewne ograniczone zmiany. Między innymi system polityczny Chin odszedł od wspomnianych masowych kampanii i przeszedł do kampanii sterowanych, tym razem prowadzonych za pomocą biurokratycznych środków. Można wnioskować, że ten manewr władz musiał być wystarczający, by pozwolić na cud gospodarczy. Dlaczego jednak partia, gotowa na gruntowne zmiany, trzymała się skompromitowanych kampanii?

Yang Yao także podkreśla ciągłość w historii Chin, ale definiuje ją odmiennie ${ }^{25}$. Jego zdaniem ta kontynuacja odnosi się do całej historii państwa, z jej specyficzną chińską organizacją polityczną, czyli merytokracją. Jest to porządek moralny, ponieważ w konfucjanizmie zasługa jest cnotą, i to najwyższą. Merytokracja to formalny system selekcji kandydatów do służby publicznej w administracji cesarskiej. Można by go uznać za niedemokratyczny, ale ma on pewne cechy demokratyczne, gdyż egzaminy są otwarte dla wszystkich chętnych, gotowych poddać się rygorystycznej selekcji. Nie jest może demokratyczny w zachodnim stylu, ponieważ kandydaci na najwyższe stanowiska nie są wybierani, lecz dobierani bardzo skrupulatnie. Ten wynalazek - zresztą pochodzenia konfucjańskiego, wymyślony przez Chiny około roku 200 p.n.e. - został oficjalnie zniesiony w 1905 r. Wtedy to zlikwidowano również system dynastyczny. Ale, jak twierdzi Yao,

${ }^{24}$ E. Perry, From Mass Campaigns to Managed Campaigns: „Constructing a New Socialist Countryside”, w: E. Perry, S. Heilman (red.), Mao’s Invisible Hand, Harvard University Press, Harvard 2011.

${ }^{25}$ Y. Yao, An Anatomy of the Chinese Selectocracy, „China Economic Journal” $11 / 3 / 2018$. 
ta praktyka trwała nawet do $1949 \mathrm{r}^{26}$ Imperialny system merytokracji został zastąpiony przez jego substytut. Ciesząca się monopolem partia - z nazwy robotnicza - stała się instrumentem selekcji na najwyższe stanowiska w administracji. A po 1978 r. przywódcy postanowili w pełni zrehabilitować pierwotny, starożytny system sprawowania władzy.

Uważam, że hipoteza powyższa jest do zaakceptowania, ponieważ koncepcja merytokracji jest nieodłączną częścią doktryny konfucjańskiej, tego nienaruszalnego elementu czy też podstawy chińskiego systemu, głęboko zakorzenionego w przeszłości tej cywilizacji. Argument ten wymaga jednak pewnego dopracowania, tak by lepiej pasował do logiki przyjętej w konfucjańskiej metodologii. Chodzi mi o to, że pierwotnym zamiarem Konfucjusza i jego zwolenników było traktowanie merytokracji jako instytucji nadrzędnej dla całego społeczeństwa. Nie ma mowy o merytokracji jako częściowym układzie - traktuje się ją raczej jako organiczną całość, która obejmuje wszystkie podmioty, w tym państwo, i która przetrwała wieki, aby zapewnić skuteczny system selekcji kandydatów do stanowisk administracyjnych. Wyjątkowa trwałość chińskiego państwa jest dowodem tego, że merytokracja sprawdziła się na tym zagregowanym poziomie. Jeśli ten schemat był dobry dla państwa, musiał też być dobry dla innych aktorów, zwłaszcza dla rodziny. Tak z pewnością jest, ponieważ zgodnie z konfucjańskim przekonaniem państwo opiera się na rodzinie. Aby państwo było merytokracją, potrzebna jest zatem najpierw merytokratyczna rodzina, której członkowie muszą być oceniani przez pozostałą jej część na podstawie ich osobistych zasług, czyli cnót. Tej zależności nie można odwrócić.

To, że Chiny mają tylko jedną partię, może być łatwo - lecz błędnie rozumiane jako dowód na to, że mamy do czynienia z systemem autokratycznym. Nie zgadza się to z faktem, że od dłuższego czasu w Chinach funkcjonuje szeroki system wyborów bezpośrednich, które nie ograniczają się do oficjalnej listy kandydatów. Wybory bezpośrednie są przeprowadzane na poziomie wsi i miasteczek, aż do szczebla powiatu. Powyżej tego progu odbywają się wybory pośrednie przez przedstawicieli, którzy z kolei wybierają przedstawicieli do organu ustawodawczego - jest nim Kongres Ludowy. Dla wielu autorów jest to zatem system dwupoziomowy, w którym niższy poziom jest demokratyczny, a górny autokratyczny ${ }^{27}$. Zasadnicza waga niższego poziomu jest jednak w mojej opinii nieporównywalnie większa niż wyższego. Podczas ostatniej rundy wyborów lokalnych zagłosowało

\footnotetext{
26 Por. ibidem.

27 Por. ibidem.
} 
aż 0,9 miliarda ludzi - to nieomal wszyscy dorośli mieszkańcy Chin. Prawdą jest także to, że uprawnieni obywatele nie mieli nic do powiedzenia w sprawie wyboru wyższych stanowisk, ale polityka z reguły dotyczy kwestii chleba i masła, która tak czy inaczej może być rozwiązywana głównie na szczeblu lokalnym. Tak więc nie ma przeszkód, aby przyjąć, że właściwie cały system obecnych Chin można postrzegać jako „demokratyczny”, choć nie w stylu zachodnim.

Proponowałbym, jako bardziej sensowne, nazywanie chińskiej alternatywy wobec zachodnich struktur swego rodzaju demokracją, na przykład demokracją z chińskimi elementami. Jeszcze trafniejsze byłoby jednak nazwanie chińskiej struktury politycznej merytokracją konfucjańską, której zasady nie dotyczą wyłącznie jakiegoś jednego segmentu czy warstwy struktury politycznej, ale obejmują całe społeczeństwo. Innymi słowy, Chiny mogą być politycznie jednolite, bez żadnych specyficznych warstw. Przyjęta konwencja polega na traktowaniu wynalezionej w Chinach merytokracji jako koncepcji państwa, ale trzeba zauważyć, że rodzina również może być merytokratyczna. Jeśli ten system jest korzystny dla sprawności państwa, powinien także sprawdzać się na poziomie rodziny. W rzeczywistości, używając metody konfucjańskiej, należałoby oczekiwać, że państwo może być merytokratyczne tylko wtedy, gdy już wcześniej rodzina działa w ten sposób. Dzieje się tak, ponieważ w podejściu konfucjańskim państwo jest produktem rodziny. Nie powinno dziwić, że aby funkcjonować tak jak państwo, rodzina musi dokonywać wyborów na podstawie zasług, a nie z innych powodów. Przyznaje więc pierwszeństwo tym, którzy najwięcej wnoszą do jej życia. Dba na przykład o to, aby najstarszy syn tak długo czekał, by stać się głową rodziny, aż będzie wystarczająco dojrzały do zajmowania się jej sprawami.

W perspektywie liberalnej rodzina jest często definiowana jako organizacja autokratyczna (lub niedemokratyczna), czego przykładem jest wybitne dzieło Hannah Arendt Kondycja ludzka ${ }^{28}$. Jest to paradoksalne, ponieważ autorka podkreśla w swych rozprawach filozoficznych centralną rolę rodziny jako siły organizującej, głównie w odniesieniu do prokreacji. Jej zdaniem, historycznie, surowy ojciec używa swojej siły do bezwzględnego podporządkowania sobie innych członków rodziny. Dlaczego jednak nie założyć odwrotnie, że sprawy rodzinne są prowadzone tak jak merytokracja, czyli są oparte raczej na cnocie (zasługach) aniżeli na władzy, czy wręcz przemocy? To, oczywiście, nie odnosi się do Chin z ich konfucjańską tradycją, dla której rodzina to oaza harmonii. Dlaczego jednak ojcowie mieliby wybierać

${ }^{28}$ H. Arendt, Kondycja ludzka, Fundacja Aletheia, Warszawa 2000. 
władzę, a nie, powiedzmy, miłość jako podstawę relacji, nie jest wcale jasne. Miłość jest warunkiem prokreacji, od której zależy przyszłość, podczas gdy siła służy tylko ochronie przed inną siłą. Dlaczego, w sposób oczywisty liczniejsi, pozostali członkowie rodziny mieliby być łatwym celem agresji działającego w pojedynkę ojca? W każdym razie Chiny nie zmierzają w stronę demokracji typu zachodniego, ale raczej w stronę społecznej a nie państwowej - merytokracji zgodnej z chińską tradycją. Konfucjańska w swojej filozofii merytokracja jest zasadniczo demokratyczna, ponieważ oceny zasług jednostek są jawne i uczciwe. Merytokracja zatem nie jest przeciwieństwem demokracji, ale raczej „bylejakości”, czyli deficytu cnót.

\section{Podsumowanie}

Zachód jest w fazie wycofywania się z pozycji gospodarczego centrum świata, a Chiny - szerzej, Wschód - znajdują się w odwrotnej sytuacji. Pokazują to zmieniające się dane demograficzne. Przy stagnacji ludności liczba mieszkańców Zachodu maleje. W krajach zachodnich nie brakuje kapitału, lecz siły roboczej. Ta nierównowaga sprawia, że sięgają one po zagranicznych pracowników. Istnieje masowa migracja, głównie ludzi młodych. Przykładowo, od transformacji systemowej zainicjowanej w 1989 r. nastąpił ogromny przepływ ludzi ze wschodu Europy (również z Polski) na zachód. W tym samym czasie Chiny (wraz z resztą Azji, w tym Indiami) kontynuowały wzrost liczby ludności. Polityka jednego dziecka w Chinach nigdy nie została zaakceptowana, a liczba osób w rejestrach stale rośnie. Teraz, spodziewając się starzenia się społeczeństwa, rząd wprowadził politykę trójki dzieci - z karami za ich brak. Dzisiejszy rząd rozumie, że ludność nie jest ciężarem, ale raczej głównym zasobem, z którego w ostatecznym rachunku bierze się bogactwo materialne.

Odpowiednim kontekstem dla badań nad Chinami nie jest ich industrializacja, która została opóźniona o cały wiek (1850-1950). Najważniejszą kwestią jest to, że - z tym poważnym wyjątkiem - Chiny zawsze były wyraźnym historycznym przykładem niekończącego się, wielkiego sukcesu. Wyrazem tego jest ich cud gospodarczy, najdłuższy we współczesnej historii. Na pewno w porównaniu z Anglią Chiny spóźniły się z budową własnego przemysłu, ale być może nawet w tym przypadku nie było to oznaką niepowodzenia, lecz raczej źródłem ich sukcesu. Opóźnienie to mogło być najlepszym dla nich rozwiązaniem, ponieważ - jak sądzę pozwoliło wybrać lepszą od liberalnej ścieżkę industrializacji. Zamiast 
odrzucić swoją starożytną kulturę i przejąć obcą, zachodnią, Chińczycy zaadaptowali swój konfucjanizm do potrzeb uprzemysłowienia. Składnikiem tej kultury jest charakterystyczny dla Chin opór przed zmianą, widoczny w całej chińskiej historii. Może to być jedna z głównych tajemnic nieporównywalnego sukcesu historycznego Chin w różnych dziedzinach życia, także w gospodarce. Nie przychodzi on łatwo, gdyż prościej jest dać się uwieść urokom nakreślonej przez kogoś idei postępu, niż pogodzić się z mozołem codziennej rutyny.

Liberałowie identyfikują ekonomię z fizyką, a zarazem oddzielają ekonomię od etyki. Konfucjaniści natomiast oddzielają ekonomię od fizyki, ale zrównują ekonomię z etyką. Czyniąc to, Chińczycy postrzegają zasady ekonomii jako normy etyczne. Ich etyka jest, oczywiście, bardziej złożona niż samo przyznanie, że jest ona podstawą egzystencji. Zgodnie z tą etyką moralność koncentruje się wokół rodziny. Najważniejszą prawdą moralną dla rodziny jest przestrzeganie hierarchii wieku - co oznacza posłuszeństwo dzieci wobec rodziców. Warunkiem takiej percepcji jest uznanie zasady imperatywu miłości jako maksymalnej i nieograniczonej odpowiedzialności wobec innych ludzi, nawet jeśli nie ma gwarancji jakiejkolwiek rekompensaty materialnej. Liberalizm głęboko wykorzenił te idee z głównego nurtu myśli - idee niegdyś centralne dla ekonomii politycznej jako nauki na temat sprawowania władzy nad innymi. W nowej roli, kraju aspirującego do pozycji lidera gospodarczego świata, Chiny będą z pewnością przypominać Zachodowi jego dawne ideały.

Warto zauważyć, że w rzeczywistości nie ma fundamentalnego konfliktu między konfucjanizmem i marksizmem. Nie ma więc konfliktu między „wiedzą instynktowną”, o którą chodzi w konfucjanizmie, a oficjalną ideologią, jaką jest marksistowska teoria społeczna. Oba systemy myślowe zapewniają wsparcie dla systemu zwanego socjalizmem lub, węziej, socjalizmem rynkowym. Głównym kierunkiem polityki współczesnych Chin jest przebudzenie cywilizacji w ramach wspomnianej przeze mnie inicjatywy zachowania starych kultur na świecie. Konfucjanizm jest traktowany przez władze nie tyle jako czynnik w polityce, ile raczej esencja chińskiej cywilizacji i źródło jej samoidentyfikacji. Te podobieństwa ideologiczne sprawiły, że marksizm stał się łatwym wyborem w 1949 r. Ułatwiły także dostosowanie go do warunków chińskich. Pokrewieństwa te wyjaśniają również, dlaczego Chiny zreformowały się po 1978 r. bez większych zakłóceń. Otóż socjalizm nakazowy, wprowadzany od 1949 r., oraz socjalizm pogodzony z rynkiem, wprowadzany po 1978 r., mimo wszystko podpadają pod tę samą kategorię - systemu socjalistycznego. 
Trudno nie zgodzić się z Justinem Linem, że - jak wspomniałem światowa ekonomia jako dyscyplina ewoluuje według stałego wzorca czy też zgodnie z pewną logiką ${ }^{29}$. Jego hipoteza zakłada, że główne centrum rozwoju myśli ekonomicznej co jakiś czas zmienia swoją lokalizację. Jeśli chodzi o dominujący na Zachodzie liberalizm, narodził się on w najszybciej się rozwijającej Wielkiej Brytanii. Jej ekonomiści w czasie rewolucji przemysłowej mieli dostęp do najlepszych wzorców i doświadczeń, mieli zatem najwięcej do powiedzenia na ten temat, co dało początek ich liberalizmowi. Kiedy produkcja kapitalistyczna weszła w fazę korporacyjnej konkurencji jako „gry strategicznej”, na czele znaleźli się ekonomiści z Ameryki, najdynamiczniejszej gospodarki w danej chwili. Obecnie jednak Chiny są najbardziej kwitnącą gospodarką światową, a więc - jak pisze Lin - raczej wcześniej niż później epicentrum wiedzy może się przenieść do Chin $^{30}$. Jak sądzę, nie można wykluczyć, że jeśli tak się stanie, centralne miejsce zajmie teoria konfucjańska, oferująca intelektualną alternatywę dla ekonomii neoliberalnej, która jest współcześnie traktowana jako aberracja ${ }^{31}$.

W takiej konfucjańskiej alternatywie nie ma miejsca na niewidzialną rękę, traktowaną przez liberałów jako samoorganizujący się mechanizm cenowy, który kieruje aktorami i utrzymuje ich w równowadze. Oczywiście, pozostawieni sami sobie ludzie będą skazani na jakąś formę rynku. Ekonomia konfucjańska zgadza się z tym, że rynek jest niejako zjawiskiem naturalnym, ale dodaje, że aby działać, rynek potrzebuje innej jeszcze siły, a mianowicie „moralnej wrażliwości”. Uwrażliwienie na dobro jest najważniejsze, gdyż to moralność pozwala na kontynuację życia. Liberalni ekonomiści nie dostrzegają również tego, że „uczucia moralne” działają jak liberalna niewidzialna ręka. Ludzie nie mogą być zmuszeni do stawania się moralną osobą - dokonuje się to spontanicznie. Kluczem do zrozumienia gospodarki jest to, że ludzie rozwijają swoje poczucie dobra tak jak język, którym mówią. Pewnego dnia dziecko zaczyna mówić, a potem wszystko idzie wyjątkowo szybko. Tak samo jest z moralnością, ponieważ ona także jest produktem wrodzonej zdolności umysłowej. Urodzeni ze zdolnością do przyswajania zasad gramatyki ludzie rodzą się też ze zdolnością do nabywania kompetencji moralnej. Ta „gramatyka moralna” dyktuje osądy ludzi. Warto zatem powtórzyć na koniec, że pierwotny moralny punkt widzenia jest jedyną prawdziwą niewidzialną ręką.

\footnotetext{
${ }^{29}$ Por. J.Y. Lin, Benti \& Changwu...

30 Por. ibidem.

31 Por. G. Kołodko, Czy Chiny zbawiq świat?, Prószyński i S-ka, Warszawa 2018.
} 


\section{Literatura}

Arendt H., Kondycja ludzka, Fundacja Aletheia, Warszawa 2000.

Brandt L., Ma D., Rawski T., From Divergence to Convergence: Reevaluating the History Behind China's Economic Boom, „Journal of Economic Literature” 52/1/2014.

Chen H., The Economic Principles of Confucius and His School, Honolulu University Press, Honolulu 1911.

Fromm E., The Art of Loving, Harper \& Row, New York 1956.

Gawlikowski K., Zachodnie i konfucjańskie podejścia do wojny, w: A. Zielonka, B. Zemka (red.), Chińska konfucjańska tradycja, Wyd. Uniwersytetu Jagiellońskiego, Kraków 2008.

Haley J., The Japanese Judiciary: Maintaining Integrity, Autonomy, and the Public Trust, w: D. Foote (red.), Law in Japan: A Turning Point, University of Washington Press, Seattle 2008.

Hobson J., Eastern Origins of Western Civilization, Cambridge University Press, Cambridge 2004.

Jacques M., When China Rules the World: The End of the Western World and the Birth of a New Global Order, The Penguin Press, London 2009.

Kang D., East Asia Before the West: Five Centuries of Trade and Tribute, Columbia University Press, New York 2010.

Kolodko G., Truth, Errors and Lies: Politics and Economics in Volatile World, Columbia University Press, New York 2011.

Kołodko G., Czy Chiny zbawiq świat?, Prószyński i S-ka, Warszawa 2018.

Kołodko G., Nowy pragmatyzm i jego znaczenie dla uczciwego gospodarowania, w: E. Mączyńska, J. Sójka (red.), Etyka i ekonomia. W stronę nowego paradygmatu, PTE, Warszawa 2017.

Kornai J., The Great Transformation of Central and Eastern Europe: Success and Disappointment, „Economics of Transition and Institutional Change” 14/2/2006.

Koźmiński A.K., Wyobraźnia gospodarki, Poltext, Warszawa 2016.

Krugman P., Increasing Returns and Economic Geography, „Journal of Political Economy” 99/3/1991.

Krugman P., Venables A., Globalization and the Inequality of Nations, „The Quarterly Journal of Economics” 110/4/1995.

Lardy N., Markets over Mao: The Rise of Private Business in China, Peterson Institute for International Economics, Washington 2014.

Lin J.Y., Benti \& Changwu: Dialogues on Methodology in Economics, Cengage Learning Asia, Peking University Press, Peking 2005.

Lin J.Y., Demystifying China Economy, Cambridge University Press, Cambridge 2017.

Lin J.Y., The Needham Puzzle: Why the Industrial Revolution Did Not Originate in China, „Economic Development and Cultural Change” 43/2/1995.

Luce E., Henry Kissinger: „We are in a very, very grave period”, „Financial Times” July 20/2018. 
Morse J., Love \& Economics. Why the Laissez-Faire Family Doesn't Work, Spence, Dallas 2001.

Murrell P., The Transition According to Cambridge, Mass., „Journal of Economic Literature” 33/1/1995.

Naughton B., Is China Socialist?, „The Journal of Economic Perspectives” 31/1/2017.

Needham J., Science and Civilization in China, vol. 2: History of Scientific Thought, Cambridge University Press, Cambridge 1956.

North D., Structure and Change in Economic History, Norton \& Norton, New York 1981.

Perkins D., Reforming China's Economic System, „,Journal of Economic Literature” 26/2/1988.

Perry E., From Mass Campaigns to Managed Campaigns: „Constructing a New Socialist Countryside”, w: E. Perry, S. Heilman (red.), Mao’s Invisible Hand, Harvard University Press, Harvard 2011.

Piketty T., Capital in the Twenty-First Century, Harvard University Press, Harvard 2014.

Popper K., The Open Society and Its Enemies, Routledge, London 1945.

Poznanski K., Confucian Economics: How is Chinese Thinking Different?, „China Economic Journal” 10/3/2017.

Poznanski K., Confucian Economics: The World at Work, „World Review of Political Economy” 6/2/2015.

Poznanski K., Poland's Protracted Transition: Institutional Change and Economic Growth in 1974-1994, Cambridge University Press, Cambridge 1996.

Poznanski K., State Condition, Foreign Influence and Alternative Models of Market Reforms in China, Russia and Eastern Europe, „International Critical Thought” 2/3/2012.

Poznański K., Ekonomia jako etyka: podejście konfucjańskie, w: E. Mączyńska, J. Sójka (red.), Etyka i ekonomia: w stronę nowego paradygmatu, PTE, Warszawa 2017.

Poznański K., Konfucjańska ekonomia jako alternatywa wobec skrajnego liberalizmu, w: E. Mączyńska (red.), Ekonomia i polityka. Wokół teorii Grzegorza W. Kołodko, Wydawnictwo Naukowe PWN, Warszawa 2019.

Pye L., Mandarin and The Cadre: China's Political Cultures, Center for Chinese Studies, University of Michigan, Ann Arbor 1988.

Romer P., The Origins of Endogenous Growth, „The Journal of Economic Perspectives” 8/1/1994.

Sakakibara E., Beyond Capitalism: The Japanese Model of Market Economics, Economic Strategy Institute, Lanham 1993.

Schumpeter J., Kapitalizm, socjalizm, demokracja, Wydawnictwo Naukowe PWN, Warszawa 2009.

Smith A., Theory of Moral Sentiments, A. Millar, in the Strand; and A. Kincaid and J. Bell, Edinburgh 1759.

Toynbee A., War and Civilization, Oxford University Press, Oxford 1950.

Wallerstein I., West, Capitalism and Modern World-System, „Review” 15/4/1992.

White L., Rural Roots of Reform Before China's Conservative Change, Routledge, London 2018.

Yao Y., An Anatomy of the Chinese Selectocracy, „China Economic Journal” 11/3/2018.

Zhang T., The Laws and Economics of Confucianism. Kinship and Property in Preindustrial China and England, Cambridge University Press, Cambridge 2017.

Zięba M., Papieska ekonomia: Kościół - rynek - demokracja, Wyd. Znak, Kraków 2016. 